\title{
Comprehensive Evaluation of the Operating Performance for Commercial Banks in China Based on Improved TOPSIS
}

\author{
Chao Li \\ School of Business \\ Renmin University of China \\ Beijing, China \\ sxh_bj@126.com
}

\author{
Caiqin Ye \\ School of Economics and Management \\ North China Electric Power University \\ Beijing, China \\ Yecaiqin819@126.com
}

\begin{abstract}
With the purpose of presenting a scientific, reasonable and feasible method to evaluate the performance of listed commercial banks, this thesis takes the current 16 listed commercial banks in China as study objects, selects their data up to 2011 and studies the performance evaluation system for listed commercial banks. First of all, based on principles of comprehensiveness and representativeness, this study builds a set of index system using cluster analysis and multiple correlation coefficient method. Secondly, analytic hierarchy process (AHP) and entropy method are used to identify the weight coefficient. Last, this paper ranks and assesses the operating performance for these commercial banks, using the improved TOPSIS method to calculate the comprehensive scores for each bank.
\end{abstract}

Keywords-commercial banks; operating performance; comprehensive evaluation; improved TOPSIS method; cluster analysis

\section{INTRODUCTION}

With the entry of foreign banks and integration of international finance, Chinese commercial banks are facing unprecedented challenges, intensifying the competition between banks. To some extent, the core competitiveness lies in the operation level and therefore, improving operating performance is the key factor for commercial banks to survive in the fierce competition. Putting more research in issues regarding to commercial banks' operating performance is not only necessary to improve their own self-management, but also prerequisite to enhance the operation and management mechanism for the entire banking industry and boost the stable and coordinated development of economy[1][2].

This paper takes the current 16 listed commercial banks in China as study objects, selects their data up to 2011 and studies the performance evaluation system for listed commercial banks. Double-classification is used to build the index system that is both comprehensive and representative. As for the determination of index weight, combination weighting of analytic hierarchy process (AHP) and entropy method are applied in order to make index system both indicative and practical. In terms of comprehensive evaluation, this thesis uses the improved TOPSIS method to calculate the comprehensive scores for each bank and assessed and ranked their operating performance.

\section{ESTABLISHMENT OF INDEX SYSTEM FOR EVALUATION OF OPERATING PERFORMANCE}

\section{A. Initial Evaluation Index System}

There are a large number of indicators to reflect commercial banks' operating performance. In order to build a comprehensive and scientific index system that can more accurately present and assess banks' performance, this thesis adopts literature summarizing method, consults predecessors' studies and existing regulations and then initially selects indexes that are able to reflect status of financial profitability, asset liquidity, asset security and development ability for these listed commercial banks[3][4][5]. This initial evaluation index system is shown in table 1 .

This paper takes the current 16 listed commercial banks in China as research objects, studies their data provided by SSE (Shanghai Stock Exchange) and 2011 annual reports of these banks and selects the above index data up to 2011 as sample. Original data is shown in table 2.

\section{B. Screening of the Evaluation Index System}

In practice, it is not the case that the more indexes the better and therefore we should use a few "key" indicators in practical evaluation process. Based on predecessors' work and the initial index system [6], this paper uses cluster analysis and multiple correlation coefficient to screen these indexes to finalize them. This kind of method both subjectively considers the economic significance of the evaluation indexes and objectively picks the representative ones.

First of all, these indexes will be dividedly into 4 categories using cluster analysis. This is achieved by entering the sample data into SPSS 12.0 software and then applying cluster analyzing the 4 categories of indexes: financial profitability indexes, asset liquidity indexes, asset security indexes and development ability indexes. The cluster analysis result is shown on figure 1 to figure 4 .

Secondly, the representative index from each category will be selected by calculating the multiple correlation coefficients. If there is only one index in a particular category, then it will automatically be selected. If the number of indexes in a 
category exceeds two, then compare calculate the multiple correlation coefficient for each index and pick the one that has the largest multiple correlation coefficient because the larger the multiple correlation coefficient the more useful information this index is supposed to provide in this category. Take the "Financial profitability" index category as an example; the process to identify the representative index is as follows.

TABLE I. INITIAL INDEX SYSTEM FOR OPERATING PERFORMANCE EVALUATION OF CHINA'S LISTED COMMERCIAL BANKS

\begin{tabular}{|c|c|c|c|c|c|}
\hline Object & $\begin{array}{c}\text { Evaluation } \\
\text { Index }\end{array}$ & Evaluation Factors & Code & Unit & Nature \\
\hline \multirow{20}{*}{ 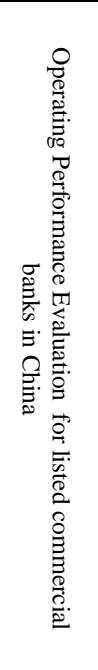 } & \multirow{6}{*}{$\begin{array}{l}\text { Financial } \\
\text { Profitability }\end{array}$} & ROAA & $\mathrm{X} 11$ & $\%$ & Positive \\
\hline & & ROE & $\mathrm{X} 12$ & $\%$ & Positive \\
\hline & & EPS & $\mathrm{X} 13$ & yuan & Positive \\
\hline & & Cost/Revenue & $\mathrm{X} 14$ & $\%$ & Inverse \\
\hline & & Per Capita Profit & $\mathrm{X} 15$ & $\mathrm{~K}$ & Positive \\
\hline & & Return on Capital & $\mathrm{X} 16$ & $\%$ & Positive \\
\hline & \multirow{3}{*}{ Asset Liquidity } & Liquidity Ratio & $\mathrm{X} 21$ & $\%$ & Moderate \\
\hline & & Loan to Deposit Ratio & $\mathrm{X} 22$ & $\%$ & Moderate \\
\hline & & Cash Reserve Ratio & $\mathrm{X} 23$ & $\%$ & Positive \\
\hline & \multirow{5}{*}{ Asset Security } & NPLR & X31 & $\%$ & Inverse \\
\hline & & Overdue Loans Ratio & $\mathrm{X} 32$ & $\%$ & Inverse \\
\hline & & Capital Adequacy Ratio & X33 & $\%$ & Positive \\
\hline & & $\begin{array}{c}\text { Core Capital Adequacy } \\
\text { Ratio }\end{array}$ & X34 & $\%$ & Positive \\
\hline & & NPL Provision coverage & $\mathrm{X} 35$ & $\%$ & Positive \\
\hline & \multirow{6}{*}{$\begin{array}{c}\text { Development } \\
\text { Ability }\end{array}$} & Revenue Growth Rate & $\mathrm{X} 41$ & $\%$ & Positive \\
\hline & & Total Assets Growth Rate & $\mathrm{X} 42$ & $\%$ & Positive \\
\hline & & Deposit Growth Rate & $\mathrm{X} 43$ & $\%$ & Positive \\
\hline & & Loan Growth Rate & $\mathrm{X} 44$ & $\%$ & Positive \\
\hline & & $\begin{array}{l}\text { Non-interest income growth } \\
\text { rate }\end{array}$ & $\mathrm{X} 45$ & $\%$ & Positive \\
\hline & & Rate of capital accumulation & $\mathrm{X} 46$ & $\%$ & Positive \\
\hline
\end{tabular}

TABLE II. ORIGINAL DATA FOR EVALUATION OF OPERATING PERFORMANCE FOR 16 LISTED COMMERCIAL BANKS IN CHINA

\begin{tabular}{|c|c|c|c|c|c|c|c|c|c|c|}
\hline BANK NAMES & $\begin{array}{l}X 11 \\
(\%)\end{array}$ & $\begin{array}{l}X 12 \\
(\%)\end{array}$ & $\begin{array}{c}\text { X13 } \\
\text { (Yuan) }\end{array}$ & $\begin{array}{l}X 14 \\
(\%)\end{array}$ & $\begin{array}{c}X 15 \\
(K)\end{array}$ & $\begin{array}{l}X 16 \\
(\%)\end{array}$ & $\begin{array}{l}X 21 \\
(\%)\end{array}$ & $\begin{array}{l}X 22 \\
(\%)\end{array}$ & $\begin{array}{l}X 23 \\
(\%)\end{array}$ & $\begin{array}{l}\text { X31 } \\
(\%)\end{array}$ \\
\hline Shenzhen Development & 1.04 & 20.32 & 2.47 & 39.99 & 962.22 & 308.01 & 51.93 & 73.49 & 18.88 & 0.53 \\
\hline Bank of Ningbo & 1.24 & 18.81 & 1.13 & 36.38 & 844.91 & 139.93 & 52.19 & 66.62 & 23.53 & 0.68 \\
\hline SPD Bank & 1.12 & 20.70 & 1.46 & 28.79 & 1136.96 & 217.19 & 42.80 & 71.48 & 19.82 & 0.44 \\
\hline Hua Xia Bank & 0.81 & 17.44 & 1.48 & 41.89 & 653.52 & 211.61 & 39.39 & 66.65 & 19.25 & 0.92 \\
\hline China Minsheng Bank & 1.40 & 23.95 & 1.05 & 35.61 & 910.71 & 139.15 & 40.90 & 72.85 & 20.23 & 0.63 \\
\hline China Merchants Bank & 1.39 & 24.17 & 1.39 & 36.19 & 1039.21 & 218.39 & 44.28 & 71.80 & 18.39 & 0.56 \\
\hline Bank of Nanjing & 1.32 & 15.87 & 1.08 & 30.97 & 952.09 & 133.02 & 39.21 & 61.51 & 19.73 & 0.78 \\
\hline Industrial Bank & 1.20 & 24.67 & 2.36 & 31.95 & 972.64 & 401.29 & 30.71 & 71.46 & 22.05 & 0.38 \\
\hline Bank of Beijing & 1.06 & 19.00 & 1.44 & 26.35 & 1553.00 & 183.02 & 33.64 & 64.41 & 20.51 & 0.53 \\
\hline $\mathrm{ABC}$ & 1.11 & 20.46 & 0.38 & 35.89 & 353.60 & 48.71 & 40.18 & 58.50 & 27.07 & 1.55 \\
\hline Bank of Communications & 1.19 & 20.49 & 0.82 & 30.13 & 726.03 & 110.80 & 35.37 & 71.94 & 22.45 & 0.86 \\
\hline ICBC & 1.44 & 23.44 & 0.60 & 29.38 & 666.03 & 78.01 & 27.60 & 63.50 & 22.53 & 0.94 \\
\hline China Everbright Bank & 1.12 & 20.44 & 0.45 & 31.95 & 856.51 & 59.88 & 37.67 & 72.28 & 18.66 & 0.64 \\
\hline China Constructi-on Bank & 1.47 & 22.51 & 0.68 & 29.79 & 665.09 & 87.64 & 53.70 & 65.05 & 23.83 & 1.09 \\
\hline Bank of China & 1.17 & 18.27 & 0.44 & 33.07 & 581.63 & 60.41 & 47.00 & 68.77 & 22.47 & 1.00 \\
\hline China CITIC Bank & 1.27 & 21.07 & 0.71 & 29.86 & 1118.16 & 96.92 & 58.97 & 73.26 & 18.62 & 0.60 \\
\hline Bank Names & $\begin{array}{l}\text { X32 } \\
(\%)\end{array}$ & $\begin{array}{l}\mathrm{X33} \\
(\%)\end{array}$ & $\begin{array}{l}\text { X34 } \\
(\%)\end{array}$ & $\begin{array}{l}\text { X35 } \\
(\%)\end{array}$ & $\begin{array}{l}\mathrm{X} 41 \\
(\%) \\
\end{array}$ & $\begin{array}{l}\mathrm{X} 42 \\
(\%)\end{array}$ & $\begin{array}{l}\mathrm{X} 43 \\
(\%) \\
\end{array}$ & $\begin{array}{l}\mathrm{X} 44 \\
(\%)\end{array}$ & $\begin{array}{l}\text { X45 } \\
(\%)\end{array}$ & $\begin{array}{l}\text { X46 } \\
(\%)\end{array}$ \\
\hline Shenzhen Development & 0.77 & 11.51 & 8.46 & 320.66 & 64.94 & 73.01 & 51.15 & 52.35 & 103.15 & 127.07 \\
\hline Bank of Ningbo & 0.73 & 15.36 & 12.17 & 240.74 & 35.25 & -1.05 & 21.20 & 20.84 & 45.88 & 17.87 \\
\hline SPD Bank & 0.51 & 12.70 & 9.20 & 499.60 & 36.23 & 22.51 & 12.84 & 16.13 & 39.20 & 21.30 \\
\hline Hua Xia Bank & 0.73 & 11.68 & 8.72 & 308.21 & 37.03 & 19.60 & 16.73 & 15.82 & 89.14 & 80.11 \\
\hline China Minsheng Bank & 0.86 & 10.86 & 7.87 & 357.29 & 50.39 & 22.23 & 16.00 & 13.96 & 97.27 & 27.41 \\
\hline China Merchants Bank & 0.83 & 11.53 & 8.22 & 400.13 & 34.72 & 16.34 & 17.02 & 14.64 & 38.80 & 23.14 \\
\hline Bank of Nanjing & 0.49 & 14.96 & 11.76 & 323.98 & 40.66 & 27.22 & 19.11 & 22.54 & 39.06 & 14.94 \\
\hline Industrial Bank & 0.63 & 11.04 & 8.20 & 385.30 & 37.77 & 30.23 & 18.76 & 15.09 & 68.44 & 26.18 \\
\hline Bank of Beijing & 0.48 & 12.06 & 9.59 & 446.39 & 32.57 & 30.45 & 10.13 & 21.17 & 69.13 & 18.48 \\
\hline $\mathrm{ABC}$ & 1.30 & 11.94 & 9.50 & 263.10 & 30.06 & 12.96 & 12.05 & 13.56 & 46.13 & 19.83 \\
\hline Bank of Communications & 0.86 & 12.44 & 9.27 & 256.37 & 21.80 & 16.69 & 14.48 & 14.52 & 26.59 & 21.97 \\
\hline ICBC & 0.74 & 13.17 & 10.07 & 266.92 & 24.79 & 15.00 & 10.01 & 14.70 & 45.90 & 16.57 \\
\hline China Everbright Bank & 0.58 & 10.57 & 7.89 & 367.00 & 29.66 & 16.81 & 15.25 & 14.22 & 29.81 & 18.03 \\
\hline China Constructi-on Bank & 0.88 & 13.68 & 10.97 & 241.44 & 22.75 & 13.61 & 10.05 & 14.59 & 28.52 & 16.52 \\
\hline Bank of China & 0.21 & 12.97 & 10.07 & 220.75 & 18.55 & 13.10 & 14.02 & 12.02 & 20.82 & 11.79 \\
\hline China CITIC Bank & 0.39 & 12.27 & 9.91 & 272.31 & 37.99 & 32.89 & 13.71 & 13.43 & 55.20 & 43.56 \\
\hline
\end{tabular}




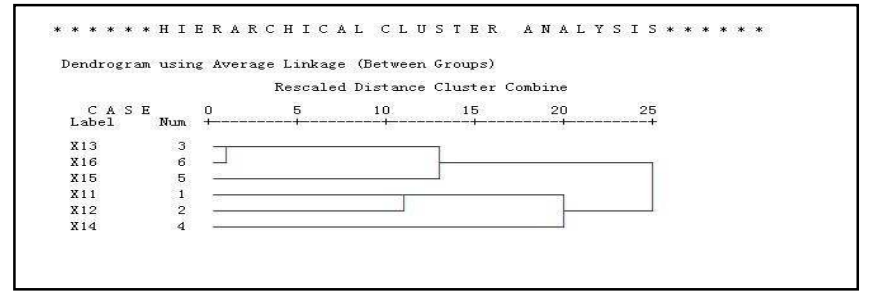

FIGURE I. EXAMPLE OF A FIGURE CAPTION. (FIGURE CAPTION)

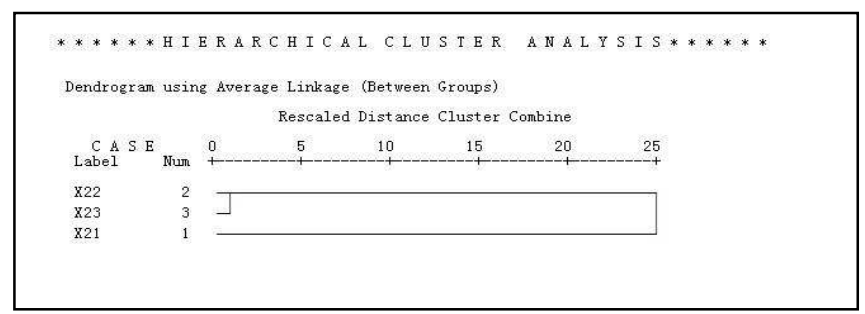

FIGURE II. EXAMPLE OF A FIGURE CAPTION. (FIGURE CAPTION)

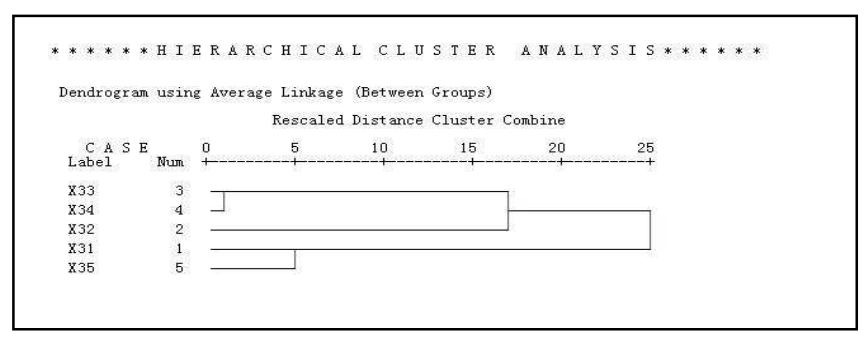

FIGURE III. EXAMPLE OF A FIGURE CAPTION. (FIGURE CAPTION)

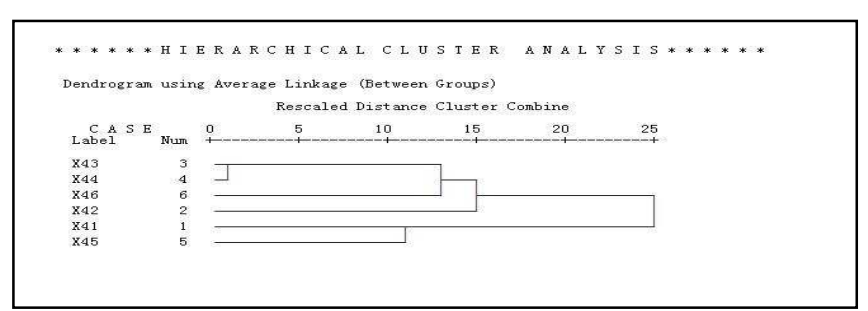

FIGURE IV. EXAMPLE OF A FIGURE CAPTION. (FIGURE CAPTION)

According to the cluster analysis result, we can further divide the 6 indexes that reflect financial profitability into two groups, with X13, X15 and X16 being group 1 and X X11, X12 and X14 being group 2. For each of the 3 indexes in group 1, we calculate its multiple correlation coefficient with the other 5 and get the following results: $R_{X 13}=0.980, R_{X 15}=0.773, R_{X 16}=0.982$. Obviously, $\mathrm{X} 16$ (return of equity) has the largest multiple correlation coefficient and it is therefore selected. Similarly, we do the calculation for each of the indexes in group 2 and get the results as follows: $R_{X 11}=0.710, R_{X 12}=0.764$ $R_{X 14}=0.724$, and again we pick X12(weight average profit margin on net asset) since it yields the largest multiple correlation coefficient. Therefore, X16 and X12 are selected as the representative indexes to reflect banks' financial profitability.
In the same way, we can select the representative indexes for the other 3 categories and form establish the final comprehensive index system for evaluating commercial banks' operating performance, as shown in table 3 .

TABLE III. COMPREHENSIVE EVALUATION INDEX SYSTEM FOR LISTED BANKS' OPERATING PERFORMANCE

\begin{tabular}{|c|c|c|c|c|}
\hline Object & $\begin{array}{c}\text { Evaluation } \\
\text { Index }\end{array}$ & Evaluation Factors & $\begin{array}{c}\text { Cod } \\
\text { e }\end{array}$ & Unit \\
\hline \multirow{8}{*}{ 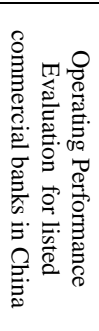 } & \multirow{2}{*}{$\begin{array}{c}\text { Financial } \\
\text { Profitability } \\
\text { Indicators } \\
\end{array}$} & ROE & $\mathrm{X} 1$ & $\%$ \\
\hline & & Return on Capital & $\mathrm{X} 2$ & $\%$ \\
\hline & \multirow{2}{*}{$\begin{array}{l}\text { Asset Liquidity } \\
\text { Indicators }\end{array}$} & Liquidity Ratio & $\mathrm{X} 3$ & $\%$ \\
\hline & & Loan to Deposit Ratio & $\mathrm{X} 4$ & $\%$ \\
\hline & \multirow{2}{*}{$\begin{array}{l}\text { Asset Security } \\
\text { Indicators }\end{array}$} & $\begin{array}{c}\text { Core Capital Adequacy } \\
\text { Ratio } \\
\end{array}$ & $\mathrm{X} 5$ & $\%$ \\
\hline & & $\begin{array}{c}\text { NPL Provision } \\
\text { coverage }\end{array}$ & X6 & $\%$ \\
\hline & \multirow{2}{*}{$\begin{array}{c}\text { Development } \\
\text { Ability Indicators }\end{array}$} & Revenue Growth Rate & $\mathrm{X} 7$ & $\%$ \\
\hline & & Deposit Growth Rate & $\mathrm{X} 8$ & $\%$ \\
\hline
\end{tabular}

III. DETERMINATION OF THE INDEX WEIGHT

In the process of multi-subject comprehensive evaluation, weighting determines the accuracy of the evaluation result. In order to avoid the arbitrariness of subjective weighting method and impracticability of objective weighting method, this thesis uses the combination of AHP method and entropy method to identify the weighting coefficient for the comprehensive index system. According to the following way:

$$
w_{j}=\beta w_{j}{ }^{1}+(1-\beta) w_{j}{ }^{2}
$$

where $w_{j}$ is the combined weight coefficient, $w_{j}{ }^{1}$ is the objective weight coefficient determined by entropy method, $w_{j}^{2}$ is the subjective weight coefficient, $1-\beta$ is the subjective preference coefficient, $\beta$ is the objective preference coefficient and $\beta \in[0,1] . \beta$ is determined by decision makers, based on the actual situation of commercial banks, background of specific assessed projects and their preferences. In this thesis, the subjective weight coefficient is set as 0.4 , the objective weight coefficient is set as 0.6 and the combined weight coefficient is therefore identified as follows:

$$
w_{j}=\left[\begin{array}{llllllll}
0.0525 & 0.272 & 0.0453 & 0.0107 & 0.1947 & 0.1035 & 0.1282 & 0.1879
\end{array}\right]
$$

\section{COMPREHENSIVE EVALUATION OF OPERATING} PERFORMANCE FOR LISTED COMMERCIAL BANKS IN CHINA

\section{A. Improved TOPSIS Method}

The traditional TOPSIS method is a way to measure a subject's comprehensive benefits according to the relative distance from ideal solution. The concept of this method is to find the positive ideal point and negative ideal point in a decision-making process and choose the alternative that has the shortest geometric distance from the positive ideal point or the largest geometric distance from the negative ideal point. However, when the geometric distance from the positive ideal point is equal to that from the positive ideal point, this method is unable to evaluate each alternative's advantages and 
disadvantages ${ }^{[9]}$. Therefore, this thesis adopts the improved TOPSIS, which uses vertical projection method, to evaluate banks' operating performance. The specific steps are listed as follows:

1) Set the number of evaluation subject as $n$, number of evaluation index as $m$, and the initial decision matrix as $X$, then,

$$
X=\left[\begin{array}{cccc}
x_{11} & x_{12} & \cdots & x_{1 m} \\
x_{21} & x_{22} & \cdots & x_{2 m} \\
\cdots & \cdots & \cdots & \cdots \\
x_{n 1} & x_{n 2} & \cdots & x_{n m}
\end{array}\right]
$$

2) Uniform all the factors in Matrix $X$.

$y_{i j}=\left\{\begin{array}{l}x_{i j}, \text { associated with the criteria having a positive impact } \\ -x_{i j}, \text { associated with the criteria having a negative impact }\end{array}\right.$

3) Uniform all the factors in Matrix $X$.

$$
z_{i j}=\frac{y_{i j}}{\left(\sum_{i=1}^{n} y_{i j}{ }^{2}\right)^{\frac{1}{2}}}
$$

4) Uniform all the factors in Matrix $X$.

$$
u_{i j}=w_{j} z_{i j}
$$

where $\omega_{j}$ is the weight coefficient identified by the combination of AHP and entropy method.

5) Uniform all the factors in Matrix $X . j=1,2, \cdots, m$

$$
\begin{aligned}
& u^{+}=\left(u_{1}^{+}, u_{2}^{+}, \cdots, u_{n}^{+}\right), u_{j}^{+}=\max \left\{u_{i j}\right\} \\
& u^{-}=\left(u_{1}^{-}, u_{2}^{-}, \cdots, u_{n}^{-}\right), u_{j}^{-}=\min \left\{u_{i j}\right\}
\end{aligned}
$$

6) Calculate the relative distance $d_{i}$ and the larger the $d_{i}$, the better the evaluation object's comprehensive benefits. Remember, $\Delta u=u^{+}-u^{-}, \Delta u_{i}=u_{i}-u^{-}$, then the relative distance $d_{i}$ between definition point $u_{i}$ and negative ideal point $u^{-}$is:

$$
d_{i}=\frac{\left\langle\Delta u_{i}, \Delta u\right\rangle}{\|\Delta u\|^{2}}, i=1,2, \cdots, n
$$

where $d_{i} \in[0,1],\left\langle\Delta u_{i}, \Delta u\right\rangle$ is the inner product of $\Delta u_{i}$ and $\Delta u,\|\Delta u\|^{2}$ is Euclidean Norm of $\Delta u$, namely,

$$
\|\Delta u\|^{2}=\left\{\sum_{j=1}^{m}\left(u_{j}^{+}-u_{j}^{-}\right)^{2}\right\}^{1 / 2}
$$

\begin{tabular}{|c|c|c|c|c|c|}
\hline Corps & $\operatorname{Score}(Z)$ & Rank & Corps & $\operatorname{Score}(Z)$ & Rank \\
\hline $\begin{array}{c}\text { Shenzhen } \\
\text { Development }\end{array}$ & 0.29625 & 1 & Bank of Beijing & 0.14313 & 8 \\
\hline Bank of Ningbo & 0.18221 & 3 & $\mathrm{ABC}$ & 0.07867 & 14 \\
\hline SPD Bank & 0.17503 & 4 & $\begin{array}{c}\text { Bank Of } \\
\text { Communications }\end{array}$ & 0.08241 & 13 \\
\hline Hua Xia Bank & 0.13654 & 9 & ICBU & 0.08547 & 12 \\
\hline China Minsheng Bank & 0.14524 & 7 & China Everbright Bank & 0.07114 & 15 \\
\hline $\begin{array}{c}\text { China Merchants } \\
\text { Bank }\end{array}$ & 0.15990 & 6 & $\begin{array}{c}\text { China Construction } \\
\text { Bank }\end{array}$ & 0.11147 & 11 \\
\hline Bank of Nanjing & 0.17401 & 5 & Bank of China & 0.07113 & 16 \\
\hline Industrial Bank & 0.22023 & 2 & China CITIC Bank & 0.12699 & 10 \\
\hline
\end{tabular}

\section{B. Comprehensive Evaluation Based on Improved TOPSIS}

According to the relative distance calculated under equation (1) to (8), the operating performance for the 16 commercial banks is ranked in table 6 .
TABLE IV. COMPREHENSIVE RANKING IN 16 LISTED COMMERCIAL BANKS IN CHINA UNDER THE IMPROVED TOPSIS METHOD

\section{Empirical Results}

According to commercial banks' nature of business, we can divide the 16 mentioned commercial banks into 3 categories: State Owned Commercial Banks (SOCB), including Agricultural Bank of China, Bank of Communications, Industrial and Commercial Bank of China, Chinese Construction Bank, national joint-stock commercial banks, including Shenzhen Development Bank, Shanghai Pudong Development Bank, Huaxia Bank, China Minsheng Bank, China Merchants Bank, Industrial Bank, China Everbright Bank, China CITIC Bank and city commercial banks including Bank of Beijing, Bank of Nanjing and Bank of Ningbo). Comprehensive assessment results show two main characteristics of commercial banks' operating performance, consistent with actual situation.

1) Positioning figures and tables national joint-stock commercial banks have better operating performance than state owned commercial banks. As shown in the results in table 6, national joint-stock commercial banks are highly ranked with better performance, especially the TOP 2, Shenzhen Development Bank and Industrial Bank. In contrast, stated owned commercial banks are mostly lowest ranked with the Big Four banks and Communication banks all ranked below 10th. With better regulated banking system, positive banking culture and comprehensive incentive mechanism, national joint-stock commercial banks have developed quickly under severe competition and improved their operating performance. As for state owned commercial banks, as they grow larger, so does the internal "inertia", which prevents their market competitiveness and profitability from improving and increasing. In spite of the better operating performance for national joint-stock commercial banks, there are vast disparities within them. Of the 16 banks, 5 national joint-stock commercial banks are highly ranked, indicating an above-theaverage operating performance. However, there are also 3 national joint-stock commercial banks that are ranked very low with operating performance below the average level.

2) City commercial banks are developing fast with robust overall strength. Among the 16 banks, the 3 city commercial are ranked 3rd, 5th and 8th respectively with high scores. It can be seen that, even though they can't compete with state owned banks and national joint-stock commercial banks in assets quality and size, city commercial banks are developing rapidly 
with increasing competitiveness due to their flexible business pattern, sharp response market and effective operation mechanism. In addition, the development of city commercial banks relies heavily on the local economy. These 3 banks are all headquartered in cities with developed economy. Strong local fiscal revenues, large number of small and medium-sized private enterprises and high per capita national income all provide a solid base for city banks' development.

\section{CONCLUSIONS AND PROSPECTS}

This thesis takes the listed commercial banks as samples, sets the index system, identifies the index weight and comprehensive assessment method, and then builds a evaluation model for commercial banks' performance and systematically analyzes how to effectively evaluate the operating performance for commercial banks' in China. However, due to lack of access to the financial data from some of these banks, the selection of samples and indexes is limited, which will have some impacts on the comprehensiveness of the evaluation results. Moreover, in the screening process for indicators, restricted by the sample data, some of the key indicators such as non-performing loan ratios are deleted, omitting their influence on the effectiveness the evaluation.

Future studies should make improvement in the following two aspects. First, selected samples should be more comprehensive. With increasing number of commercial banks, research in their operating performance will become more difficult and therefore proper selection of samples will enhance the quality and accuracy of evaluation results. Secondly, in order to get a better evaluation of listed commercial banks' operating performance, data studied should not be restricted to financial indicators. A combination of financial and nonfinancial indicators will help to assess banks' operating performance more comprehensively and scientifically.

\section{ACKNOWLEDGMENT}

I would like to particularly show my best gratitude to my supervisor, Dr. Song, who has provide me with valuable guidance in every stage of the writing of this paper.

\section{REFERENCES}

[1] Zhang, H. W., Wang, K,Y. Comprehensive evaluation of operating performance for joint-stock commercial banks in China (in Chinese). Hainan Finance, (02), 16-18 (2009)

[2] Zhang, Q., Pan, H. X. The empirical research on the efficiency of commercial banks in China (in Chinese). Journal of Regional Financial Research, (09), 61-65 (2011)

[3] George E. H., Dimitrios S. S. Efficiency measurement of the Greek commercial banks with the use of financial ratios: a data development analysis approach. Management Accounting Research, (15), 201-224 (2004)

[4] Zhao, X. X., Zhang, Q. W. Comprehensive evaluation of operating performance for listed commercial banks in China (in Chinese). Business Economy ,(17):89-90, 2010

[5] Hu, Z. F., Wang, T. T., Wang, S. Y. Operating performance of China's commercial banks---an analysis based on 14 listed banks' data in 2009 (in Chinese). Finance Forum, (05), 43-47 (2011)

[6] Zhang, L. J., Luo, Z. Evaluation indicator screening method for listed companies' operating performance (in Chinese). Statistics and Decision, (18), 63-65 (2008)

[7] Jiang, L. M. Application of AHP method in comprehensive evaluation of commercial banks' operating performance (in Chinese). Statistics \& Information Tribune, (02), 29-32 (2002)

[8] Xie, C., Zhong, Z. Entropy method and its application in comprehensive evaluation of bank's performance (in Chinese). China Soft Science, (09), 108-110 (2002)

[9] Zeng, W. Comprehensive evaluation of bank's operating strength based on entropy coefficient and TOPSIS method (in Chinese). Statistics and Decision, (19), 76-78 (2007) 